\title{
Pengaruh Lembaga Keuangan Mikro Agribisnis Terhadap Peningkatan Pendapatan Anggota Gabungan Kelompok Tani (Studi Pada desa Barebbo Kecamatan Barebbo)
}

\author{
Wahyuni \\ Institut Agama Islam Negeri (IAIN) Bone \\ wahyuni@yahoo.co.id \\ Firdaus \\ Sekolah Tinggi Agama Islam (STAI) Al -Furqan Makassar \\ firdaus@gmail.com
}

\begin{abstract}
This study discusses the effect of Agribusiness Microfinance Institutions on Increasing Income of Combined Farmer Group Members (Study in Barebbo Village, Barebbo Subdistrict). This study aims to find out (1) whether the Micro Agribusiness Financial Institution influences the increase in income of members of the Joint Farmer Group in the village of Barebbo. The results of the study showed that parking retribution on the side of public roads contributed significantly to local revenues only in 2013 because of the APAD $\angle M P A D$, while parking fees on the side of public roads did not contribute significantly to local revenues in 2012, 2014, 2015 and 2016 due to $A P A D>M P A D$.
\end{abstract}

Keywords: Institute of Microfinance, Agrabisnis, Penadapatan.

\section{Abstrak}

Penelitian ini membahas Pengaruh Lembaga Keuangan Mikro Agribisnis Terhadap Peningkatan Pendapatan Anggota Gabungan Kelompok Tani (Studi Pada desa Barebbo Kecamatan Barebbo) . Penelitian ini bertujuan untuk mengetahui (1) Apakah Lembaga Keungan Mikro Agribisnis berpengaruh terhadap peningktan pendapatan anggota Gabungan Kelompok Tani di desa Barebbo. Hasil penilitian menunjukkan bahwa retribusi parkir ditepi jalanan umum berkontribusi signifikan terhadap pendapatan asli daerah hanya terjadi pada tahun 2013 karena $A P A D<M P A D$, sedangkan retribusi parkir ditepi jalanan umum berkontribusi tidak signifikan terhadap pendapatan asli daerah terjadi pada tahun 2012, 2014, 2015 dan 2016 karena APAD $>$ MPAD.

Kata kunci: Lembaga Keuangan Mikro, Agrabisnis, Penadapatan.

\section{PENDAHULUAN}

Jurnal Ilmiah Al Tsarwah

Program Magister Program Studi Ekonomi Syariah

Institut Agama Islam Negeri (IAIN) Bone 
Lembaga Keuangan Mikro adalah lembaga keuangan yang khusus didirikan untuk memberikan jasa pengembangan usaha dan pemberdayaan masyarakat, baik melalui pinjaman atau pembiayaan dalam usaha skala mikro kepada anggota dan masyarakat, pengelolaan simpanan, maupun pemberian jasa konsultasi pengembangan usaha yang tidak semata-mata mencari keuntungan. ${ }^{1}$

Permodalan menjadi salah satu permasalahan utama yang dihadapi pelaku usaha pertanian. Untuk mengatasi masalah tersebut, pemerintah memberikan solusi dengan meluncurkan suatu program yang dinamakan program Pengembangan Usaha Agribisnis Pedesaan (PUAP) melalui pemberian dana Bantuan Langsung Masyarakat (BLM) sebagai modal usahatani bagi petani, sekaligus untuk memperbaiki dan memperkuat kelembagaan ekonomi di pedesaan yang akhirnya bermuara pada berkembangnya Lembaga Keuangan Mikro Agribisnis (LKMA) di pedesaan. ${ }^{2}$

Kementrian pertanian menyatakan bahwa kegiatan LKM-Agribisnis terus dikembangkan sebagai wahana pengelolaan dana Bantuan Langsung Masyarakat (BLM) dalam program Pengembangan Usaha Agribisnis Perdesaaan. Keberadaan LKM-Agribisnis dalam PUAP menjadi keharusan untuk mengelola keuangan Gabungan Kelompok Tani (Gapoktan). Menurut pusat pembiayaan pertanian LKM-Agribisnis dijadikan salah satu unit permodalan Gapoktan yang ditumbuhkembangkan atas inisiatif petani anggota kelompok tani dalam Gapoktan tersebut.

Pemerintah melalui Dinas Pertanian berusaha menyalurkan dana kepada petani melalui Gapoktan (Gabungan Kelompok Tani) yang ada di masing-masing wilayah. Dana ini berasal dari APBN yang selanjutnya diberikan langsung kepada pelaku agribisnis dalam bentuk Bantuan Langsung Masyarakat (BLM) melalui Gapoktan yang ada di setiap wilayah. Pola BLM ini berlanjut pada Program Pengembangan Usaha Agribisnis (PUAP) yang dilaksanakan oleh Departemen Pertanian pada Tahun 2007 dan dilakukan secara terintegrasi dengan Program Nasional Pemberdayaan

${ }^{1}$ http://www.ojk.go.id/lembaga-keuangan-mikro.

2 Hari Hermawan dan Harmi Andrianyta, Lembaga Keuangan Mikro Agribisnis: Terobosan Penguatan Kelembagaan danPembiayaan Pertanian di Pedesaan, Dokumen, Balai Besar Pengkajian dan Pengembangan Teknologi, 2012, h. 143 
Masyarakat Mandiri (PNPM-M). Untuk pelaksanaan Pengembangan Usaha Agribisnis Perdesaan (PUAP) di Departemen Pertanian, Menteri Pertanian membentuk tim Pengembangan Usaha Agribisnis Pedesaan melalui Keputusan Menteri Pertanian (KEPMENTEN) Nomor 545/Kpts/OT.160/9/2007.3

LKM-Agribinis di desa Barebbo didirikan pada tahun 2008, dengan tujuan sebagai wadah untuk membantu permodalan para petani di desa Barebbo. Dengan akses permodalan yang relatif mudah dibandingkan lembaga keuangan lainnya, diharapkan agar anggota kelompok tani semakin meningkat dan tetap loyal untuk mengambil modal di LKM-A.

Penumbuhan LKM-A di dalam Gapoktan PUAP merupakan langkah strategis untuk menyelesaikan persoalan pembiayaan petani mikro dan buruh tani yang selama ini sulit mendapatkan pelayanan keuangan lembaga keuangan formal. Sebagai langkah pemberdayaan lebih lanjut dari Gabungan Kelompok Tani (Gapoktan) Pengembangan Usaha Agribisnis Perdesaan menjadi LKM-A dimaksudkan untuk memberikan kepastian pelayanan serta kemudahan akses petani pada fasilitas pembiayaan, prosedur yang sederhana dan cepat, kedekatan lokasi pelayanan dengan tempat usaha petani. ${ }^{4}$

Modal dalam usaha tani diklasifikasikan sebagai bentuk kekayaan, baik berupa uang maupun barang yang digunakan untuk menghasilkan sesuatu secara langsung atau tak langsung dalam suatu proses produksi. Pembentukan modal bertujuan untuk meningkatkan produksi dan pendapatan usaha tani, serta menunjang pembentukan modal lebih lanjut. ${ }^{5}$ Dalam pengembangan pertanian, ketersediaan modal dalam jumlah cukup dan tepat waktu merupakan unsur penting dan strategis. Modal bentuk uang tunai sangat diperlukan bukan hanya untuk memenuhi kebutuhan sehari-hari, tetapi lebih daripada itu untuk membeli sarana produksi pertanian. Misalnya bibit, pupuk, dan

${ }^{3}$ Azye Dessy Ulfa, Analisis Peranan Pembiayaan Murabahah pada Lembaga Keuangan Mikro Agribisnis (LKM-A) Berbasis Syariah Terhadap Tingkat Pendapatan Anggota, Skripsi, Universitas Andalas Padang, 2012, h. 1

4 Hilman, Pengaruh Kebijakan PUAP Terhadap Implementasi Lembaga KeuanganMikroAgribisnis (LKMA) di Kabupaten Tangerang, Jurnal IImiah IImu Administrasi, h. 89

${ }^{5}$ Rita hanafie, Pengantar Ekonomi Pertanian, Ed. I (Yogyakarta: CV. Andi Offset, 2010), h. 95

Jurnal Ilmiah Al Tsarwah 
lain-lain yang memungkinkan petani melakukan proses produksi, yang selanjutnya untuk mendapatkan uang dari hasil penjualan produk usaha taninya. ${ }^{6}$

Pengembangan sektor pertanian saat ini menghadapi banyak tantangan dan kendala seperti rendahnya kualitas sumber daya manusia di pedesaan, makin terbatasnya sumber daya lahan, kecilnya status dan luas kepemilikan lahan, terbatasnya akses petani terhadap permodalan. Selain itu masih lemahnya kapasitas kelembagaan petani dan penyuluh, masih terbatasnya kemampuan sistem perbenihan dan perbibitan nasional, masih rawannya ketahanan pangan dan energi, masih rendahnya nilai tukar petani dan kurang harmonisnya koordinasi kerja antar sektor terkait merupakan hambatan di dalam pembangunan pertanian. ${ }^{7}$

Masyarakat menginginkan suatu lembaga keuangan yang tidak menerapkan sistem bunga, yang mudah dijangkau oleh petani, dan tidak memerlukan persyaratan agunan. Salah satu lembaga yang muncul adalah Lembaga Keuangan Mikro Agribisnis (LKM-A) dengan prinsip bagi hasil, sehingga LKM-A ini tergolong lembaga keuangan syariah karena menerapkan sistem bagi hasil. ${ }^{8}$ Dengan adanya sistem bagi hasil tersebut, maka akan berpengaruh terhadap pendapatan petani.

Salah satu upaya pemberdayaan petani yang berbasis kelompok yaitu kelompok Gapoktan (Gabungan Kelompok Tani) Mattugengkeng di Desa Barebbo, Kecamatan Barebbo, Kabupaten Bone. Desa Barebbo merupakan salah satu penerima BLM untuk program Gapoktan. Program Gapoktan ini dijalankan berdasarkan sistem kelompok. Kelompok Gapoktan ini sudah dilaksanakan sejak tahun 2008 dan masih berjalan hingga sekarang. Kelompok SPP ini terdiri dari 10 kelompok yang setiap kelompok terdiri dari 10 orang. Berdasarkan pada latar belakang masalah diatas maka penulis merumuskan permasalahan sebagai pembahasan pokok yang akan dibahas pada pembahasan selanjutnya. Rumusan masalah itu sebagai berikut Apakah

\footnotetext{
${ }^{6}$ Hilman, Op. Cit, h. 98

${ }^{7}$ Triane Widya Anggriani, Analisis Dampak Pelaksanaan Program Pengembangan Usaha AgribisnisPerdesaan (PUAP), Citapen, Bogor, Skripsi,Universitas Indonesia Jakarta, 2012, h. 3

${ }^{8}$ Helmi Ria, Peranan Lembaga Keuangan Mikro Agribisnis (LKM-A) Terhadap Pengembangan Teknologi Budidaya Ubi Jalar Dalam Upaya Meningkatkan Pendapatan Petani, Kecamatan Baso, Skripsi, Universitas Andalas Jakarta, 2010, h. 2
} 
Lembaga Keungan Mikro Agribisnis berpengaruh terhadap peningktan pendapatan anggota Gabungan Kelompok Tani di desa Barebbo.

\section{METODE}

\section{Sumber dan Teknik Pengumpulan Data}

Menurut Mc. Leod sebagaimana yang dikutip oleh Husein Umar, pengertian data dari sudut ilmu sistem informasi sebagai fakta-fakta maupun angka-ankga yang secara relatif tidak berarti bagi pemakai. ${ }^{9}$ Data sendiri terdiri atas dua, yaitu sebagai berikut :

a) Data primer. Adalah jenis data yang diperoleh dan digali dari sumber utamanya (sumber asli), baik berupa data kualitatif maupun data kuantitatif. ${ }^{10}$ Data primer dikumpulkan dengan metode observasi dan angket. Metode ini diterapkan untuk mengungkap informasi secara mendalam mengenai pengaruh Lembaga Keuangan Mikro Agribisnis dalam meningkatkan pendapatan anggota Gabungan Kelompok Tani (Gapoktan) dalam meningkatkan kesejahteraan di desa Barebbo kecamatan Barebbo.

b) Data sekunder. Adalah jenis data yang diperoleh dan digali melalui hasil pengolahan pihak kedua dari hasil penelitian lapangan, baik berupa data kualitatif maupun data kuantitaif. ${ }^{11}$ Data sekunder diperoleh dari data yang telah diolah oleh pihak lain atau dari kepustakaan. Data-data yang bersumber dari buku-buku literatur yang berhubungan dengan kajian teori yang menunjang penyusunan laporan ini.

Adapun teknik pengumpulan data adalah cara yang dapat digunakan oleh peneliti untuk mengumpulkan data. ${ }^{12}$ Teknik pengumpulan data dapat dilakukan dengan

${ }^{9}$ Husein Umar, Metode Penelitian untuk Skripsi dan Tesis Bisnis, Ed. Baru (Cet. II; Jakarta : PT. RajaGrafindo Persada, 1999), h. 41.

${ }^{10}$ Muhammad Teguh, Op.Cit., h. 122.

${ }^{11}$ lbid.

${ }^{12}$ Maman Abdurrahman dan Sambas Ali Muhidi, Op.Cit., h. 85. 
4 cara, yaitu observasi, kuesioner (questioner), interview (wawancara) dan dokumentasi. Namun, dalam penelitian ini hanya menggunakan tiga macam teknik pengumpulan data, yaitu sebagai berikut :

a) Observasi. Yaitu pengamatan dan pencacatan sesuatu obyek dengan sistematika fenomena yang diselidiki. ${ }^{13}$ Teknik obsevasi merupakan salah satu teknik pengumpulan data yang digunakan peneliti untuk mengadakan pengamatan dan pencacatan secara sistematis terhadap objek yang diteliti, baik dalam situasi buatan yang secara khusus diadakan (laboratorium) maupun dalam situasi alamiah atau sebenarnya. ${ }^{14}$ Instrumen observasi dalam penelitian ini digunakan untuk menghimpun berbagai macam keterangan (data) yang dilakukan dengan cara melakukan pengamatan dan pencatatan secara sistematis terhadap peningkatan pendapatan anggota yang mengambil modal pada Lembaga Keuangan Mikro Agribisnis (LKM-A) di desa Barebbo.

b) Kuesioner (Questioner). Disebut pula sebagai angket atau self administrated questioner adalah teknik pengumpulan data dengan cara mengirimkan suatu daftar pertanyaan keapada responden untuk diisi. ${ }^{15}$ Alat pengumpulan data dengan kuesioner adalah daftar pertanyaan yang disiapkan oleh peneliti untuk disampaikan kepada responden (anggota Gabungan Kelompok tani) yang jawabannya diisi oleh responden sendiri.

\section{Variabel Penelitian}

Variabel adalah karakteristik yang akan diobservasi dari satuan pengamatan. Karakteristik yang dimiliki satuan pengamatan itu berbeda-beda (berubah-ubah) atau memiliki gejala yang bervariasi dari satu-satuan pengamatan pada satu-satuan pemgamatan lainnya, atau, untuk satuan pengamatan yang sama, karakteristiknya berubah menurut waktu atau tempat. ${ }^{16}$

\footnotetext{
${ }^{13}$ Sugiyono, Op.Cit., h. 67.

${ }^{14}$ Maman Abdurrahman dan Sambas Ali Muhidi, Loc.Cit.

${ }^{15}$ Sugiyono, Op.Cit., h. 78.

${ }^{16}$ Maman Abdurrahman dan Sambas Ali Muhidi, Op.Cit., h. 73.

Jurnal Ilmiah Al Tsarwah

Program Magister Program Studi Ekonomi Syariah

Institut Agama Islam Negeri (IAIN) Bone
} 
Variabel secara umum dibedakan menjadi dua macam, yaitu sebagai berikut:

a) Variabel independen atau variabel bebas ( $X)$ adalah variabel yang mempengaruhi atau menyekan terjadinya perubahan pada variabel dependen (terikat). ${ }^{17}$ Dengan demikian, dinamakan sebagai variabel bebas karena bebas mempengaruhi variabel lainnya. Adapun variabel bebas dari penelitian ini adalah pengaruh LKM-Agribisnis diberi simbol $(\mathrm{X})$.

b) Variabel dependen atau variabel terikat $(Y)$ adalah variabel yang dipengaruhi atau yang menjadi akibat karena adanya vaiabel bebas. Adapun variabel dependen (terikat) dalam penelitian ini adalah pendapatan anggota Gabungan Kelompok Tani (Gapoktan) (Y).

\section{HASIL DAN PEMBAHASAN}

\section{Hasil Uji Prasyarat Regresi}

Sebelum proses analisis data, uji prasyarat terhadap data-data penelitian dilakukan terlebih dahulu. Uji prasyarat yang dimaksud yaitu: uji normalitas, uji linearitas, dan uji multikolinearitas. Uji prasyarat tersebut dapat dipaparkan sebagai berikut:

a. Uji Normalitas

Uji normalitas dimaksudkan untuk mengetahui apakah data untuk semua variabel dalam penelitian ini mengikuti pola distribusi normal ataukah tidak. Jika datanya berdistribusi normal maka bisa menggunakan metode analisis statistik parametrik, tetapi jika datanya tidak berdistribusi normal maka menggunakan metode statistik non parametrik. Pengujian normalitas dilakukan dengan teknik KolmogorovSmimov dengan kriteria untuk nilai signifikansinya $>10 \%$ atau 0,1 . Jika $>0,1$ data

${ }^{17}$ lbid., h. 74.

Jurnal Ilmiah Al Tsarwah

Program Magister Program Studi Ekonomi Syariah

Institut Agama Islam Negeri (IAIN) Bone 
berdistribusi normal, jika $<0,1$ data tidak berdistribusi normal. Dengan menggunakan batuan komputer program SPSS versi 21.0 for Windows, hasil uji nomalitas dengan teknik Kolmogorov-Smimov ternyata berdistribusi normal karena nilai signifikansi untuk semua variabel $>0,1$ yaitu 2,075 (Selengkapnya hasil uji normalitas dapat dilihat pada halaman lampiran, halaman 98).

b. Uji Linearitas

Uji linearitas bertujuan untuk mengetahui apakah hubungan antara variabel dependen dengan masing-masing variabel independen dalam penelitian ini mempunyai hubungan linear atau tidak. Jika data berbentuk linear, penggunaan analisis regresi sederhana pada pengujian hipotesis dapat dipertanggungjawabkan. Tetapi jika tidak linear maka harus digunakan analisis regresi non linear. Untuk memastikan data bersifat linear atau tidak dapat dilakukan dengan cara melihat nilai signifikansi linearity-nya, apabila $>0,1$ maka terdapat hubungan linear secara signifikan antara variabel independen dengan variabel dependen. Sebaliknya, jika nilai signifikansi linearity-nya $<0,1$ maka tidak terdapat hubungan linear antara variabel independen dengan variabel dependen.

Hasil uji linearitas antara Pengaruh LKM-Agribisnis $(X)$ dan Peningkatan pendapatan Anggota Gapoktan ( $\mathrm{Y}$ ) adalah signifikan, artinya terdapat hubungan linear antara variabel independen dengan variabel dependen. (Selengkapnya hasil uji linearitas regresi dapat dilihat pada lampiran, halaman 98).

\section{Hasil Uji Regresi}

Sebagaimana yang telah dijelaskan pada III (Metode Penelitian) bahwa metode yang digunakan dalam menganalisis data pada penelitian ini adalah regresi linear sederhana. Regresi linear sederhana digunakan untuk menguji seberapa besar pengaruh variabel LKM-Agribisnis $(\mathrm{X})$ terhadap Peningkatan Pendapatan Anggota Gapoktan (Y) di Desa Barebbo Kecamatan Barebbo. Kriteria pengujian yaitu dengan nilai signifikansi 0,1 (10\%), jika nilai signifikansi $F$ atau t statistiknya $<0,1$ maka ada pengaruh signifikan variabel independen terhadap variabel dependennya, jika $>0,1$

Jurnal Ilmiah Al Tsarwah 
maka tidak ada pengaruh signifikan. Perangkat yang digunakan dalam meregresi data penelitian ini adalah programSPSS versi 21 for Windows. Hasil uji regresi yang diperoleh dapat dipaparkan pada tabelberikut:

Tabel. Hasil Uji Regresi

\begin{tabular}{|l|c|c|c|c|c|}
\hline $\begin{array}{c}\text { Variabel } \\
\text { Dependen }\end{array}$ & $\begin{array}{c}\text { Variabel } \\
\text { Independen }\end{array}$ & $\begin{array}{c}\text { Kofisien } \\
\text { Regresi }\end{array}$ & t-Stat & Sig. & Status \\
\hline $\begin{array}{l}\text { Pendapatan } \\
\text { Anggota } \\
\text { Gapoktan } \\
(\mathrm{Y})\end{array}$ & $\begin{array}{c}\text { AKM- } \\
\text { Agribisnis } \\
(\mathrm{X})\end{array}$ & 0,220 & 1,020 & 0,013 & Signifikan \\
\hline Kofisien Konstanta & 34,709 & F-Statistic & 1,040 \\
\hline Sig. (Konstanta) & 0,076 & $\begin{array}{l}\text { Sig.(F- } \\
\text { Statistic) }\end{array}$ & 0,013 \\
\hline $\mathrm{R}$ & 0,146 & R2 & 0,021 \\
\hline
\end{tabular}

Sumber : Data Primer Diolah, 2017

Hal-hal yang dapat disimpulkan dari hasil uji regresi tersebut di atas, adalah sebagai berikut:

1) Hasil persamaan regresi yang didapatkan, yaitu:

$\mathrm{Y}=34,709+0,220 X$

Penjelasan mengenai persamaan regresi tersebut di atas, dapat dipaparkan sebagai berikut:

a. Nilai koefisien konstantanya sebesar 34,709 yang artinya jika $X$ nilainya nol, atau pengaruh LKM-Agribisnis terhadap Peningkatan Pendapatan Anggota Gapoktan adalah sebesar 34,709.

b. Koefisien regresi LKM-Agribisnis $(X)$ adalah sebesar 0,220. Artinya jika variabel independen $\mathrm{X}$ mengalami kenaikan $1 \%$ maka pendapatan anggota Gapoktan akan mengalami peningkatan sebesar 0,220. T-statistiknya adalah positif, artinya terjadi hubungan positif antara LKM-Agribisnis $(\mathrm{X})$ dengan Peningkatkan Pendapatan Anggota Gapoktan (Y) di Desa Barebbo Kecamatan Barebbo. 
2) Nilai signifikasi ( $p$ value) T-statistik

Nilai signifikansi ( $p$ value) t-stastistik yang didapatkan adalah $C=0,076$ dan $X=0,313$. Artinya, variabel LKM-Agribisnis berpengaruh secara signifikan terhadap Peningkatan Pendapatan Anggota Gapoktan di Desa Barebbo. Dengan demikian, model persamaan regresi yang digunakan adalah sangat baik dalam memprediksi variabel independen yang digunakan terhadap variabel dependennya.

1) Nilai signifikasi ( $p$ value) F-statistik $=0,313$

Nilai signifikasi ( $p$ value) F-statistik sebesar 0,313 yang arrtinya variabel LKM-Agribisnis berpengaruh secara signifikan terhadap Peningkatan Pendapatan Anggota Gapoktan di Desa Barebbo.

\section{Hasil Uji Korelasi (R)}

Uji ini menunjukkan seberapa besar hubungan yang terjadi antara variabel independen dan variabel dependen. Kriterianya yaitu nilai $R$ berkisar antara 0 sampai 1 . Jika nilainya semakin mendekati 1 berarti hubungan yang terjadi semakin kuat, sebaliknya jika nilainya semakin mendekati 0 maka hubungan yang terjadi semakin lemah.

\section{Tabel. Hasil Uji Korelasi}

\begin{tabular}{|l|c|r|r|r|}
\hline Model & $\mathbf{R}$ & R Square & $\begin{array}{c}\text { Adjusted R } \\
\text { Square }\end{array}$ & $\begin{array}{c}\text { Std. Error of } \\
\text { the Estimate }\end{array}$ \\
\hline 1 & $0,146^{\mathrm{a}}$ & 0,021 & 0,001 & 9,360 \\
\hline
\end{tabular}

Sumber : Data Primer Diolah, 2017

Berdasarkan tabel di atas, hasil uji korelasi (R) sebesar 0,146 artinya kofisien korelasinya adalah tinggi. Hal ini menunjukkan bahwa terjadi hubungan yang tinggi antara variabel LKM-Agribisnis (X) dengan Peningkatan Pendapatan Anggota Gapoktan di Desa Barebbo (Y).

\section{Hasil Uji Determinasi $\left(\mathbf{R}^{2)}\right.$}


Uji Determinasi $\left(R^{2}\right)$ digunakan untuk mengetahui besarnya persentase variabel independen dalam mempengaruhi variabel dependennya. Nilai $R^{2}$ bekisar antara 0 - 1. Jika nilai $R^{2}$ makin mendekati 0 maka kemampuan variabel independen menjelaskan variasi variabel dependennya semakin kecil. Sebaliknya, jika $R^{2}$ mendekati 1 maka kemampuan variabel independen menjelaskan variasi variabel dependennya semakin besar. Pengaruh semua variabel independen mampu menjelaskan variansi variabel dependen semakin besar. Uji Determinasi juga digunakan untuk mengetahui besarnya kontribusi variabel pengaruh LKM-Agribisnis (X) dalam mempengaruhi Peningkatan Pendapatan Anggota Gapoktan di Desa Barebbo.

Tabel. Hasil Uji Determinasi

\begin{tabular}{|l|c|r|r|r|}
\hline Model & $\mathbf{R}$ & R Square & $\begin{array}{c}\text { Adjusted R } \\
\text { Square }\end{array}$ & $\begin{array}{c}\text { Std. Error of } \\
\text { the Estimate }\end{array}$ \\
\hline 1 & $0,146^{\mathrm{a}}$ & 0,021 & 0,001 & 9,360 \\
\hline
\end{tabular}

Sumber : Data Primer Diolah, 2017

Dari hasil uji determinasi menunjukan bahwa besarnya kontribusi variabel pengaruh LKMA $(\mathrm{X})$ dalam mempengaruhi peningkatan pendapatan anggota Gapoktan di Desa Barebbo adalah sebesar 0,021 artinya variabel independen yang digunakan berpengaruh besar terhadap variabel dependennya.

\section{Pembahasan Hasil Analisis}

Setelah dilakukan pengujian hipotesis di atas, pada bagian ini akan dilakukan pembahasan. Pembahasan akan difokuskan pada penjelasan mengenai temuan penelitian ini yang sesuai dengan fakta di Desa Barebbo Kecamatan Barebbo.

Dari hasil uji hipotesis di atas menunujukkan bahwa variabel LKM-Agribisnis berpengaruh secara signifikan dan berkorelasi positif dengan Peningkatan pendapatan Anggota Gapoktan ( $t=1,020, p=0,313$ ). Meskipun berpengaruh signifikan akan tetapi bukan satu-satunya variabel yang berpengaruh terhadap peningkatan pendapatan anggota gapoktan, karena kontribusinya terhadap 
Peningkatan Pendapatan Anggota Gapoktan hanya 0,021. Hal demikian menunjukkan pengaruh variabel yang diuji lebih kecil dibandingkan variabel lain yang tidak diuji. Ini dikarenakan tidak semua anggota kelompok Gapoktan bisa atau mudah akrab dengan anggota kelompok lain, terkadang ada anggota yang masih bersifat individualis. Meskipun demikian, variabel ini (LKM-Agribisnis) merupakan hal yang harus terus dijaga dan diperbaiki oleh semua anggota kelompok Gapoktan Mattugengkeng.

Fakta dilapangan menunjukkan bahwa petani yang tegabung dalam kelompok Gapoktan Mattugengkeng sudah produktif karena sudah memiliki penghasilan dari usaha tani yang dijalankan. Dari hasil penelitian ini dengan 50 responden, membuktikan bahwa dengan memberikan penambahan modal (pupuk) untuk usaha yang lebih produktif dapat meningkatkan pendapatan bagi para petani.

\section{KESIMPULAN DAN SARAN}

\section{Kesimpulan}

Berdasarkan hasil analisis dan pembahasan di atas, maka dapat ditarik kesimpulan sebagai berikut:

1) Dari hasil uji regresi di atas menunujukkan bahwa variabel Pengauruh LKMAgribisnis berpengaruh secara signifikan dan berkorelasi positif dengan Peningkatan Pendapatan Anggota Gapoktan di Desa Barebbo $(t=1,020, p=$ $0,313)$.

2) Besarnya pengaruh variabel LKMA terhadap Peningkatan Pendapatan Anggota Gapoktan dari hasil uji analisis regresi yang dilakukan, yaitu sebesar 0,021.

Secara umum dapat disimpulkan bahwa program Pemerintah PNPM Mandiri Perdesaan berjalan dengan baik dengan terlihat pada salah satu programnya yaitu Gapoktan mampu meningkatkan pendapatan petani dan meningkatkan pendapatan rumah tangga bagi penerima manfaatnya.

\section{Saran}


Berdasarkan kesimpulan di atas maka dapat disarankan hal-hal sebagai berikut:

1) Konsep dari PNPM Mandiri Pedesaan dengan program PUAP melalui penerapan Sistem Kelompok Tani cukup sukses dalam memberdayakan petani yang tegabung dalam kelompok Gapoktan Mattugengkeng. Untuk itu diharapkan bertambahnya kelompok Gapoktan di wilayah yang belum tersentuh oleh program PUAP.

2) Peran dari pemerintah desa, kecamatan, maupun fasilitator sangat diperlukan untuk memberi pengarahan bagi kelompok-kelompok Gapoktan agar mampu lebih produktif dan dapat meningkatkan pendapatan usaha tani.

3) Diharapkan kelompok-kelompok Gapoktan terus ada dan berkembang baik itu difasilitasi oleh pemerintah maupun swasta agar para petani juga dapat memiliki penghasilan dengan usaha tani mereka.

\section{DAFTAR PUSTAKA}

Abdullah, Ma'ruf, Metodologi Penelitian Kuantitatif untuk: Ekonomi-ManajemenKomunikasi-IImu Sosial Lainnya, Cet. 1; Yogyakarta: Aswaja Pressindo, 2015

Abdurrahman, Maman dan Sambas Ali Muhidi, Panduan Praktis Memahami Penelitian: Bidang Sosial-Administrasi-Pendidikan, Cet. 1; Bandung : CV Pustaka Setia, 2011

Bahreisy, Salim dan Said Bahreisy, Terjemah Tafsir Singkat Ibnu Katsir Jilid IV, Surabaya: Bina Ilmu, 1988

Chapra, M. Umer, Islam dan Tantangan Ekonomi, Jakarta: Gema Insani Press, 2000

Departemen Agama RI, Al-Qur'an dan Terjemahnya, Cet. 3; Jakarta: Departemen Agama Rl, 2010

Dessy, Azye Ulfa, Analisis Peranan Pembiayaan Murabahah pada Lembaga Keuangan Mikro Agribisnis (LKM-A) Berbasis Syariah Terhadap Tingkat Pendapatan Anggota,Skripsi 2012

Emzir, Metodologi Penelitian Pendidikan: Kuantitaitf dan Kualitatif, Ed. 1, Cet. 2; Jakarta: PT. RajaGrafindo Persada, 2009 
Fahrudin, Pengantar Kesejahteraan Sosial, Bandung: Refika Aditama, 2012

Hadjar, Ibnu, Dasar-dasar Metodelogi Penelitian Kuantitatif dalam Pendidikan, Ed. 1. Cet. II ; Jakarta: PT Rajagfindo Persada, 1999

Hanafie, Rita, Pengantar Ekonomi Pertanian, Ed. I, Yogyakarta: CV. Andi Offset, 2010 